3 Calancie B, Nordin M, Wallin U, Hagbarth KE. Motor unit responses in human wrist flexor and extensor muscles to transcranial cortical stimuli. $\mathcal{F}$ Neurophysiol 1987; 58:1168-85

4 Claus D, Mills KR, Murray NMF. The influence of vibration on the excitability of alpha motoneurones. Electroencephalogr Clin Neurophysiol 1988;69:431-6.

5 Hess CW, Mills KR, Murray NMF. Responses in small hand muscles from magnetic stimulation of the human brain. $\mathcal{f}$ Physiol 1987;388:397-419.

6 Hess CW, Mills KR, Murray NMF, Schriefer TN. Magnetic brain stimulation: central motor conduction studies in multiple sclerosis. Ann Neurol 1987;22: studies $744-52$.

7 Ingram DA, Swash $M$. Central motor conduction is abnormal in motor neuron disease. $\mathcal{F}$ Neurol Neurosurg Psychiatry 1987;50:159-66.

8 Roesler K, Hess CW, Schmid UD. Investigation of facial motor pathways by electrical and magnetic stimulation: sites and mechanisms of excitation. $尹$ Neurol Neurosurg Psychiatry 1989;52:1149-56.

9 Schriefer TN, Mills KR, Murray NMF, Hess CW. Evaluation of proximal facial nerve conduction by transcranial magnetic stimulation. $f$ Neurol Neurosurg Psychiatry 1988;51:60-6.

10 Skorpil V, Zverina E. Conduction velocity in brain nerves in man (abstract): Electromyography 1962;2:306.

11 Redmond MD, Benedetto M. Hypoglossal nerve conduc- tion in normal subjects. Muscle and Nerve 1988;11: 447-52.

12 Ishpekova B, Baykoushev S. A method of $n$ hypoglossus conductivity measurement. Presentation at annual session of scientific EEG, EMG and clinical neurophysiology association, Sofia, 20 February 1982. Folia Medica 1982;24:40-2.

13 Roesler KM, Hess CW, Heckmann R, Ludin HP. Significance of shape and size of the stimulating coil in magnetic stimulation of the human motor cortex. Neurosci Lett 1989;100:347-52.

14 Penfield $W$, Boldery E. Somatic motor and sensory representation in the cerebral cortex of man as studied by sentation in the cerebral cortex of man as studical
electrical stimulation. Brain 1937;60:389-443.

15 Cruccu G, Berardelli A, Inghilleri M, Manfredi $M$ Functional organization of the trigeminal motor system in man. Brain 1989;112:1333-50.

16 Willoughby EW, Anderson NE. Lower cranial nerve motor function in unilateral vascular lesions of the cerebral hemisphere $B M \mathcal{F} 1984 ; 89: 791-4$.

17 Dimitrijevic MR, Dimitrijevic MM, Faganel J, Sherwood AM. Suprasegmentally induced motor unit activity in paralyzed muscles of patients with established spina cord injury. Ann Neurol 1984;16:216-21.

18 Fries W, Danek A, Witt T. Motor responses after transcranial electrical stimulation of cerebral hemispheres with a degenerated pyramidal tract. Ann Neurol 1991; 29:646-50.

\section{Robert Bentley Todd (1809-60) and Todd's paralysis}

Habitués of King's College, London, are familiar with the Todd Prize and with Todd ward. One of 16 siblings, Todd's father's (Charles Hawkes Todd) other occupation was that of a well-known surgeon in Dublin. Bentley Todd, pupil of Robert J Graves, was author of many publications devoted to the anatomy and physiology of the nervous system. He published Diseases of the brain and other affections of the nervous system (1854); and edited the 6000 page Cyclopaedia of anatomy and physiology in five volumes (1835-59) celebrated for its scope and his scientific originality. ${ }^{1}$

Todd distinguished "three kinds of convulsions"the jactitating or choreic, tetanic or tonic, and clonic or epileptiform, but he is best known for his account of postepileptic paralysis described in the Lumleian lecture:

A paralytic state remains sometimes after the epileptic convulsion. This is more particularly the case when the convulsion has affected only one side or one limb: that limb or limbs will remain paralytic for some hours, or even days, after the cessation of the paroxysm, but it will ultimately perfectly recover. $^{2}$

Hughlings Jackson acknowledged the Todd and Robertson theory that the local paralysis after an epileptic seizure was due to exhaustion. He worked on peripheral neuritis, physiology of the afferent and efferent pathways of the cord. He helped the foundation of the first school of nursing with Florence Nightingale at St John's House, Queen Square, London.

Born in Dublin, Todd graduated with a BA at Trinity College and LRCSI, then moved to Pembroke College, Oxford, graduating in 1833. He was anatomist, physiologist, and physician, lectured at the Aldersgate Medical school and replaced Herbert
Mayo as Professor of Physiology at King's College (1836-53), and became its first Dean. ${ }^{3} \mathrm{He}$ was a Fellow of the Royal Society and a founder of King's College Hospital in 1840. Amongst many distinguished pupils was his friend Sir William Bowman, FRS whose work On the structure and uses of the Malpighian bodies of the kidney disclosed the capsule and basement membrane of the renal tubules; Bowman's membrane in the eye and his account of the ciliary muscle are well recognised.

Censor at the Royal College of Physicians, Todd gave the Goulstonian lectures (1839), Croonian lectures (1842) on "Practical remarks on gout, rheumatic fever and chronic rheumatism of the joints", and the Lumleian lectures (1849-50) "On the pathology and treatment of convulsive disease."

His seminal work on spinal cord disease, in volume 3 of the Cyclopaedia (1847) is almost certainly the first description of locomotor ataxy (tabes dorsalis) four years before Romberg and 11 years before Duchenne.

He believed in the efficacy of hard liquor which he prescribed indiscriminately, and sadly, died of alcoholic cirrhosis, when leaving his consulting room in Brook street. Had he lived longer he would almost certainly have been a founder member of staff of the National Hospital, Queen Square, London which started in 1860, the year of his premature death. JMS PEARCE
304 Beverley Road, Anlaby,
Hull HU10 $7 B G$

See also p. 359.

1 Lyons JB. The neurology of Robert Bentley Todd. In Rose FC, Bynum WE, eds. Historical aspects of the neurosciences. New York: Raven Press. 1982;137-50.

2 Todd RB. On the pathology and treatment of convulsive diseases. London Med Gaz 1849;8:668.

3 Hearnshaw FJC, Centenary History of King's College, London, 1929.

4 Todd RB. Cyclopaedia of anatomy and physiology, vol 3. London: Longman and Roberts, Longman, Brown Green, 1847:721. 